\title{
Perspectives on Affirmative Action in Academic Dental Institutions: The U.S. Supreme Court Rulings in the University of Michigan Cases
}

\author{
Melanie R. Peterson, D.M.D., M.B.A.; Joan E. Kowolik, B.D.S.; Gary Coleman, D.D.S., \\ M.S.; Susan Dietrich, D.M.D.; Ana Karina Mascarenhas, B.D.S., M.P.H., Dr.P.H.; \\ Michael McCunniff, D.D.S., M.S.; George Taylor, D.M.D., Dr.P.H.
}

Abstract: In June 2003 the U.S. Supreme Court upheld the constitutionality of using race as a factor in higher education admissions decisions. This article considers the impact of the Supreme Court decisions on admissions procedures at selected academic dental institutions (ADI) and their parent institutions. We interviewed fifty-eight leaders considered to be individual stakeholders at seven ADI and their related parent institutions, state dental associations, and state legislatures using a common set of questions about the Supreme Court decisions. Educators from the ADI and their parent institutions were consistent in their responses that the rulings upheld affirmative action as necessary to achieve diversity. State organized dentistry officials did not appear to be as aware as others of the rulings, whereas legislators were mixed in their responses. Except for the University of Michigan undergraduate admissions procedures, it remains to be seen what the impact will be for other higher education institutions and for academic dental institutions. Although the rulings have provided guidelines for achieving diversity using race/ ethnicity as one of several factors, the rulings will possibly be challenged, thus requiring vigilance on the part of parent institutions and their ADI to ensure compliance with the spirit of the rulings and to avoid attack from opponents of affirmative action.

Dr. Peterson is Associate Dean for Clinics and Postdoctoral Education, University of Louisville School of Dentistry; Dr. Kowolik is Assistant Professor, Pediatric Dentistry Division, Indiana University School of Dentistry; Dr. Coleman is Director of Oral Diagnosis, Baylor College of Dentistry; Dr. Dietrich is Director of Graduate Dental Education, Lutheran Medical Center; Dr. Mascarenhas is Director, Division of Dental Public Health, Boston University School of Dental Medicine; Dr. McCunniff is Associate Professor, Department of Dental Public Health \& Behavioral Sciences, University of Missouri-Kansas City School of Dentistry; and Dr. Taylor is Associate Professor, Department of Cariology, Restorative Sciences, and Endodontics, University of Michigan School of Dentistry. Direct correspondence and requests for reprints to Dr. Melanie Peterson, School of Dentistry, Room 218, University of Louisville, 501 S. Preston Street, Louisville, KY 40292; 502-852-2288 phone; 502-852-7163 fax; mrpeterson@louisville.edu.

Key words: affirmative action, diversity, admissions policy, racial/ethnic minorities, University of Michigan Supreme Court rulings, underrepresented minorities (URM)

Submitted for publication 5/18/04; accepted 7/5/04

$\mathrm{W}$ ill the recent U.S. Supreme Court rulings on affirmative action have a significant impact on dentistry and higher education? In the United States of America the problems associated with equality for all have a long and troubled history. The 1950s and 1960s saw the beginning of desegregation of housing, employment, education, and public accommodation. The development of the phrase "equal opportunity" to signify the removal of the classifications of "for colored" and "for white" followed. In 1961 President John Kennedy used the phrase "affirmative action" in ordering contractors to employ individuals "without regard to their race, creed, color, or national origin." Subsequently, the Civil Rights Act (1964) declared it unlawful to discriminate on the basis of race in employment and other public endeavors. Affirmative action programs in education relied upon various mechanisms to provide some special consideration for minority applicants to academic programs. These programs arose from concerns with unequal educational opportunities based on racial segregation and discrimination, as well as from a belief that integrated institutions could provide better learning environments for all students.

The U.S. Supreme Court first considered the use of race in educational admissions in Regents of the University of California v. Bakke (1978). The University of California had specifically set aside a certain number of positions in the freshman medical class for minority applicants. Mr. Bakke sued on the argument that he was denied admission because he 
was Caucasian, thus allegedly violating Title VI of the Civil Rights Act and the Equal Protection Clause of the Fourteenth Amendment which says that "no state shall make or enforce any law which shall abridge the privileges or immunities of citizens of the United States; nor shall any state deprive any person of life, liberty, or property, without due process of law; nor deny to any person within its jurisdiction the equal protection of the laws." Although the Supreme Court ruled in favor of Mr. Bakke, affirmative action in higher education was ruled permissible provided it was done within "strict scrutiny." The requirements for strict scrutiny involved the establishment of a compelling state interest for the use of race and the consideration of race in a "narrowly tailored" manner such that it would be one of many factors to be considered. The use of quotas to reach a "critical mass," as the University of California had done, was considered illegal.

After the controversial Bakke decision, in Hopwood v. Texas (1996) the Fifth U.S. Circuit Court of Appeals banned the use of race as an admissions factor in the states of Texas, Mississippi, and Louisiana. Other states, including California, Washington, and Florida, also enacted legislation or initiatives limiting the use of race/ethnicity in admissions decisions.

The Supreme Court became involved in this issue once again in response to two suits filed in Michigan in 1997, Gratz v. Bollinger and Grutter v. Bollinger (undergraduate and law school admissions, respectively). Again, both suits claimed that the use of race violated the Equal Protection Clause of the Fourteenth Amendment and Title VI of the Civil Rights Act. In June 2003 the Supreme Court ruled against the undergraduate school and upheld the law school admissions procedures with the following ruling:

The Law School's narrowly tailored use of race in admissions decisions to further a compelling interest in obtaining the educational benefits that flow from a diverse student body is not prohibited by the Equal Protection Clause, Title VI or Sec. 1981.

Conversely, the court ruled that the undergraduate school was using a point system that treated groups of applicants differently based upon their race, therefore violating the Civil Rights Act and the Fourteenth Amendment. The court ruled that the following admissions criteria be satisfied:
1. Demonstrate a compelling state interest for diversity.

2. Demonstrate that admissions procedures are tailored so that race is only one of several factors under consideration.

3. Refrain from using quotas, racial balancing, or separate admissions tracks for minority students.

4. Periodically review admissions procedures to determine if diversity can be achieved without special consideration for race. (Note also that the court expressed an expectation that race would no longer need to be a factor in twentyfive years.)

5. If possible, make efforts to achieve diversity using "race-neutral" alternatives. ${ }^{1}$

A parallel issue to admissions criteria involves legal challenges to, and subsequent elimination of, race-based scholarships, so that these scholarships are now based solely on socioeconomic status. ${ }^{2}$

For the purposes of this article, diversity is defined within an affirmative action framework in relation to the three population groups (African Americans, Hispanics, and Native Americans) that constituted underrepresented minorities (URM) at the University of Michigan and that are also underrepresented at many other institutions. However, our investigation indicates that universities have generally adopted a broader definition of diversity that includes not only race/ethnicity, but economic status, gender, and sexual orientation as well. Our interviews indicate that universities and dental schools believe that it is desirable to achieve a critical mass of URM. The purpose of this article is to consider the impact of the Michigan decisions on admissions procedures at selected ADI and their parent universities.

\section{Methods}

We are fellows in the 2003-04 ADEA Leadership Institute class and represent seven academic dental institutions (ADI) located in Massachusetts, New York, Texas, Missouri, Michigan, Indiana, and Kentucky. The ADIs consist of five state-supported dental schools, one private dental school, and one hospital with postdoctoral dental residency programs with training sites in several states. Each ADI varies with respect to class size and racial diversity of students and faculty. This is a qualitative study in which we identified comparable stakeholders to interview 
at the ADI, parent institution, state organized dentistry, and legislative levels using a common set of questions (Table 1). We felt that these groups could provide a variety of perspectives about affirmative action in higher education. Each author conducted a minimum of seven interviews; a total of fifty-eight stakeholders were interviewed during the fall of 2003. Those interviewed included dental school deans; the officials to whom the deans report; university provosts (or those in equivalent positions at the institutions of the authors), university presidents, university counsels; state dental society executive directors; and state legislators who were representatives of the dental school districts and chairs of state healthrelated committees. A copy of the questions was forwarded to each interviewee prior to a personal interview designed to last thirty to forty-five minutes. We assured all interviewees of confidentiality with respect to their responses.

The questions were designed to introduce elements of the diversity issue within the context of the Supreme Court decisions, and interviewees were encouraged to introduce related topics as a reflection of their beliefs on the subject. Responses were evaluated to identify patterns for each institution. The following sections summarize the responses obtained from stakeholders who represented each of the fol-

\section{Table 1. Interview questions}

1a. What is your reaction to the Supreme Court rulings?

1b. Has the current mechanism here ever been challenged?

2a. How does the parent institution define its diversity goals?

2b. How does the state define its goals for diversity in higher education?

3a. Will the existing policy change?

$3 \mathrm{~b}$. If yes, what is the planning process to change the existing policy?

3c. If yes, what is the timeline for changing the existing policy?

$3 \mathrm{~d}$. If there is to be no change in existing policy, why?

4a. What do you see as the impact of the changes you implement?

4b. How will this decision affect state legislatures?

5. How do you/will you evaluate the effectiveness of your policy?

6. Do you see diversity as a strategic advantage? Why? Why not?

7. Will this have an impact on the curriculum?

8. What do you foresee as the impact of this decision on the diversity of oral healthcare providers in this state? lowing groups: educators, organized dentistry, and legislators.

\section{Reaction to the Decisions}

The Educators. Thirty-eight educators from the ADI and their parent institutions were interviewed. Dental school deans, the officials to whom the deans report, university provosts (or their equivalent), university presidents, and university counsels were consistent in their responses and in their support of affirmative action. They expressed agreement, pleasure, and, in some cases, relief that the rulings upheld affirmative action as necessary in order to achieve the diversity that is essential to enrich student experience and to appropriately prepare them for an increasingly diverse and interdependent world. With the exception of the Michigan undergraduate school, it was felt that the rulings would cause little change in admissions procedures at the parent institution or ADI levels because applicants are already considered on individual merit. None of the interviewees indicated that academic standards would or could not be maintained as a result of the rulings. However, financial aid earmarked exclusively for designated URM was identified as an issue causing concern for some parent institutions and ADI. Several ADI interviewees mentioned the potential to relieve access to care and health care disparity problems with a more diverse workforce.

Organized Dentistry. A total of six stakeholders representing organized dentistry were interviewed. These individuals were the directors of their respective state dental societies. Two interviews were denied. These interviewees agreed with educators regarding the advantage of having a diverse student population, but they were not uniformly in favor of affirmative action to accomplish the goal and did not appear to be as aware of the rulings as were the educators. There was some concern expressed about the potential for compromising educational quality. Two interviewees felt that only "the best and the brightest" should be admitted so that professional standards would be maintained. One interviewee expressed the opinion that initiatives for minority leadership are being managed at a national level and therefore do not need to be addressed at the state level. One state dental society executive director declined the interview because that dental society did not have a policy on diversity. Several interviewees stated that bud- 
getary issues were a more pressing concern that currently took precedence over diversity efforts.

The Legislators. A total of ten legislators from seven states were interviewed. The state legislative interviewees were mixed in their responses to the Supreme Court rulings. One legislator, for example, indicated that a "compelling state interest" for creating a diverse student population in universities had not been proven; another said that the rulings rectified historical discrimination without hurting individual rights; yet another expressed the opinion that reverse discrimination could be a negative consequence of efforts to obtain a diverse student population in higher education. Like the organized dentistry interviewees, legislators expressed concerns about compromising academic standards and raised the issue of "reverse" discrimination.

There did not appear to be a pattern for the interviewees from each state with respect to state diversity initiatives, or even whether they are present or clearly defined. Each state has its own particular set of issues relating to diversity, some mandated at a federal level and others driven by factors such as economics, politics, and location. Most interviewees at all levels indicated that campus diversity should reflect that of the population. In Texas the legislature has set high diversity goals as a result of the growing number of minorities of lesser socioeconomic status. These socioeconomically disadvantaged minorities will lower the tax base and cause the state to become progressively poorer if the trend continues.

\section{Impact of the Rulings}

The University of Michigan is the only institution in our project that has been legally challenged on its admissions procedures. As a result of the $\mathrm{Su}-$ preme Court rulings, the University of Michigan revised its undergraduate admissions process for the entering class of 2004. None of the ADI indicated a specific change in admissions procedures due to the Supreme Court rulings although parent institutions (except Michigan) and their ADI indicated that the rulings will have little impact on them because existing diversity efforts are already addressing the problem. Most ADI and their parent universities indicated their intention to carefully review the rulings with university counsel to ensure compliance with the spirit of the rulings and to ensure that standards are being applied according to the Supreme Court guidelines. They also indicated they do not specifically use race/ethnicity in their admissions process, but view applicants on an individual basis.

Concern and disappointment were expressed, especially by the educators, about the interpretation of the rulings and the potential for later action at the lower court and legislative levels to undermine the rulings. Since the Supreme Court is unlikely to address the issue again in the foreseeable future, it will likely fall to the lower federal courts to determine the lawfulness of particular race and ethnicity-conscious higher education programs. An example is Hopwood v. Texas where the Bakke decision was invalidated by the lower court while yet another case at the University of Washington Law School was upheld. ${ }^{3}$ As a result, colleges and universities may be left wondering about legal standards because it seems that both the details and the context will determine the outcome.

Another outcome of the Supreme Court rulings is the emergence of efforts to initiate legislative challenges. One of the foremost opponents of affirmative action is Ward Connerly, founder and chairman of the American Civil Rights Institute. Connerly is responsible for introducing Proposition 209 that legally overturned affirmative action in California (1996). His supporters are pushing to include the "Michigan Civil Rights Act" on the November 2004 ballot in that state. This pending ballot initiative is an attempt to get Michigan voters to adopt a state constitutional amendment to outlaw any consideration of race, national origin, or gender in admissions and in other policies and practices at public institutions. Connerly plans to continue his organized advocacy campaign against affirmative action across the country. ${ }^{4}$ California and Washington have already passed similar initiatives, and a similar legislative effort was recently narrowly defeated in Colorado. The Center for Equal Opportunity (CEO) has contacted several universities and threatened to file complaints with the U.S. Department of Education's Office for Civil Rights if schools continue using race/ ethnicity in admissions decisions. In particular, the $\mathrm{CEO}$ has focused on race-exclusive programs. The CEO contends that such programs should instead focus on the underrepresentation of, and obstacles faced by, students who are economically disadvantaged. 


\section{Discussion}

The results of these interviews with stakeholders in seven states suggest uncertainty as to whether the Supreme Court rulings upholding affirmative action will improve diversity in dental educational institutions and the dental profession. Responses were not uniform: ADI interviewees were supportive of affirmative action, while the responses of organized dentistry representatives and legislators were mixed. Dental schools in particular are aware of the growing shortage of URM in the profession. From 1995-96 through 2001-02, there was a decline in dental school enrollment of African Americans and a slight increase for Hispanics while Native American enrollment remained the same. ${ }^{5}$ Two-thirds of the growth in the U.S. population from 1990 to 1997 can be attributed to an increase of racial/ethnic minority populations. If this trend continues, the number of minority dentists in the workforce will need to triple by 2050 in order to meet the need. ${ }^{6}$ This situation becomes even more relevant because it has been shown that minority populations are more adversely affected by oral health problems and that minority dentists tend to treat a disproportionately higher number of patients of their own ethnic group. ${ }^{7}$

The paradoxical situation in Texas is noteworthy. There, the state legislature has set high diversity goals for public-funded universities, but race/ ethnicity was, until the Michigan rulings, disallowed in admissions decisions as a result of the Hopwood ruling. As a result of the recent Supreme Court rulings, Texas universities, which were previously only able to use economic and geographic factors to recruit URM, can now use race/ethnicity as a factor in admissions decisions. The University of Texas at Austin and Rice University (private), also located in Texas, have announced they will return to using race/ ethnicity for the fall 2004 class.

Since the topic for this study was selected by the Leadership Institute authors with guidelines defined by the institute, a limitation is that the project was confined to the institutions of the authors - although the institutions themselves are diverse geographically, with representation from the East, Midwest, and South. Another limitation is the difficulty in selecting unbiased questions and in obtaining unbiased responses in an interview format, thus leading to the qualitative nature of the project.

\section{Conclusion}

It remains to be seen whether the Supreme Court rulings upholding affirmative action will improve diversity in education or simply create more confusion given the conflicting decisions that have been issued by lower courts. In our study, the rulings did not seem to change the personal perspectives of any interviewees. Supporters for and against affirmative action indicated that their positions were validated by the rulings. Although parent institutions (except Michigan) and their ADI indicated that the rulings will have little impact on them because existing diversity efforts are already addressing the problem, they did indicate that all admissions procedures will be carefully reviewed to ensure that standards are being applied according to the Supreme Court guidelines. They also indicated they do not specifically use race/ethnicity in their admissions process, but view applicants on an individual basis. All institutions in this study, but not all states, had defined diversity initiatives, and all indicated a desire to improve campus diversity. Although the rulings have provided guidelines for achieving diversity using race/ethnicity as one factor, the rulings will likely continue to be challenged, thus requiring more vigilance than ever on the part of parent institutions and their ADI to ensure compliance with the spirit of the rulings and to avoid attack from opponents of affirmative action.

While some educators are encouraged that race/ ethnicity can now be openly considered, there is a growing awareness that admissions policies must be carefully scrutinized, documented, and implemented according to the Supreme Court guidelines. It is also clear that the issue of affirmative action in admissions policies is far from resolved.

\section{Acknowledgments}

The authors would like to thank the interviewees who participated in this project. We would also like to express our appreciation for the support of the ADEA Leadership Institute advisors: Dr. Karl Haden, Dr. Bruce Graham, Dr. Denise Kassebaum, and Dr. William Kotowicz. 


\section{REFERENCES}

1. Schmidt P. Affirmative action survives, and so does the debate. Chronicle of Higher Education Special Report, July 4, 2003.

2. Mangan $\mathrm{K}$. The unusual rules for affirmative action in medical schools. Chronicle of Higher Education, November 24, 2000.

3. Hogan \& Hartson LLP. Affirmative action in higher education after Grutter v. Bollinger and Gratz V. Bollinger. White Paper. Washington, DC: American Council on Education, September 2003.
4. Connerly W. Taking it to Michigan. National Review Online, July 8, 2003.

5. Noonan A, et al. The need for diversity in the health professions. J Dent Educ 2003;65:9.

6. Harper H. Challenges and opportunities for oral health in communities of color. Office of Minority Health, DHHS Newsletter, July 1999:3.

7. Brown LJ, Lazar V. Minority dentists: why do we need them? closing the gap. Washington, DC: Office of Minority Affairs, U.S. Department of Health and Human Services, July 1999:6-7. 